\title{
PODELJENA PRIZNANJA ZA RAZVIJANJE KAKOVOSTI IZOBRAŽEVANJA ODRASLIH
}

\begin{abstract}
A ndragoški center Slovenije je letos prvič podelil priznanja organizacijam in posameznikom, ki prednjačijo pri načrtnem presojanju dosežene ravni kakovosti svojega dela, na podlagi ugotovljenih rezultatov pa uvajajo spremembe in novosti, da bi kakovost svojega dela še izboljšali. Gre za organizacije, kjer je skrb za kakovost del strategije vodstva in zaposlenih, ki temelji na odgovornosti do udeležencev izobraževanja, podjetij, financerjev, lokalnega okolja in stroke. Kakovost se presoja s samoevalvacijo, pri tej pa o izidih presojanja in ukrepih za izboljšanje kakovosti razpravljajo in sodelu-
\end{abstract}

\section{Podelitev priznanj za razvijanje kakovosti v izobraževanju odraslih}

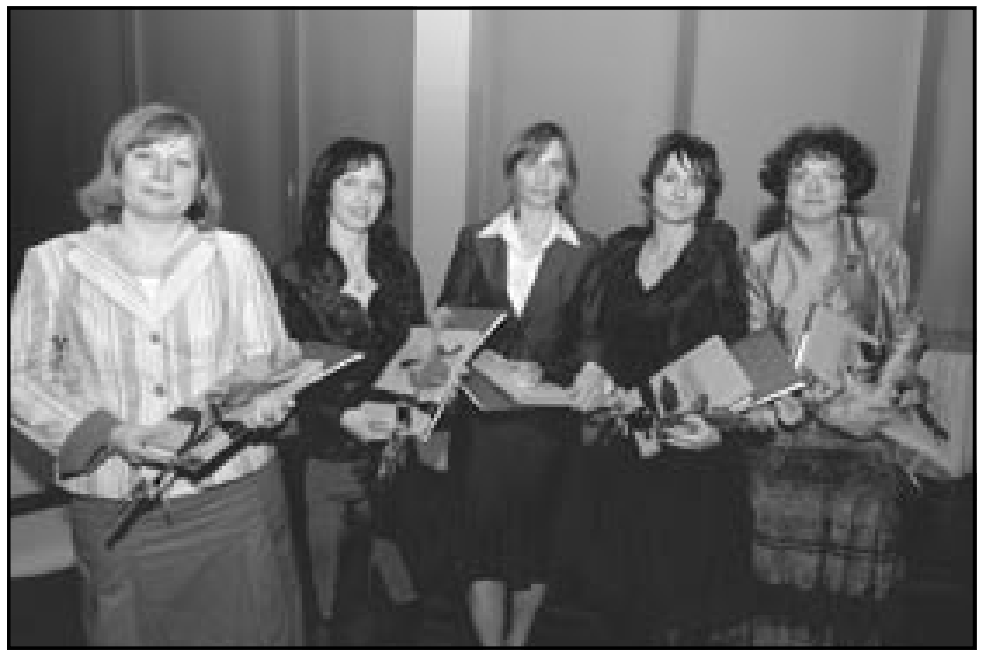

jejo vsi zaposleni. Izobraževalna organizacija veliko vlaga $v$ pridobivanje novega znanja zaposlenih za razvoj kakovosti. Priznanje za posameznike pa je namenjeno tistim strokovnjakom, ki se odlikujejo pri sodelovanju $\mathrm{v}$ vseh opisanih procesih in veliko vlagajo $\mathrm{v}$ svoje spopolnjevanje na tem področju.

Priznanja se podelijo vsaki dve leti največ trem organizacijam in trem posameznikom, ki dosegajo merila, kakršna je določil svet Andragoškega centra Slovenije (http://poki. acs.si/priznanja/pravilnik/), preverja pa jih Odbor za podeljevanje priznanj. Odbor se je letos odločil, da podeli priznanje dvema organizacijama in trem posameznicam, priznanja pa so bila podeljena na priložnostni slovesnosti 6. marca 2007. Poleg članov Odbora so dobitniki prejeli priznanje iz rok nekate- rih andragogov in andragoških delavcev, ki so $\mathrm{v}$ preteklih letih v razvoju slovenskega izobraževanja odraslih odigrali najvidnejše vloge, take, brez katerih danes ne bi mogli imeti tako kakovostnega izobraževanja odraslih: dr. Ane Krajnc, dr. Zorana Jelenca, mag. Jožeta Valentinčiča, dr. Jurija Juga, mag. Marije Velikonja, Milene Malovrh in Olge Drofenik.

Kdo so dobitniki priznanj za razvijanje kakovosti v izobraževanju odraslih 2007 ? 


\section{DOBA MARIBOR}

Doba se je razvila $v$ eno izmed najboljših izobraževalnih organizacij v Sloveniji. Vlaganje v razvoj zaposlenih, spodbujanje inovativnosti in prizadevanje za odličnost so tiste strateške poteze, ki so ustvarile Dobo, kakršno poznamo danes. V prvem obdobju po nastanku so zaposleni v Dobi med prvimi znali okolju, ki je dalo velik davek spremembam gospodarskega in političnega sistema, ponuditi različne izobraževalne programe za brezposelne in manj izobražene, da bi jim tako omogočili zaposlovanje $\mathrm{v}$ drugačnih in zahtevnejših razmerah. Že kmalu so začeli odpirati možnosti tudi za zahtevnejše strokovno izobraževanje odraslih. Hitro in kakovostno odzivanje na potrebe okolja je prvo vodilo njihove kakovosti, drugo pa razvojno delo. Ne čakajo, da bi se na državni ravni razvili novi programi, novi prijemi, temveč ustvarjajo novosti tudi sami. Tretji ključ kakovosti Dobe pa je prav gotovo skrb za odrasle, ki se učijo pri njih. Skrb za kakovost in razvoj zaposlenih v Dobi se kaže tudi v tem, da si je ta organizacija že leta 2002 pridobila certifikat kakovosti ISO, nekaj let pozneje pa se je kot prva izobraževalna organizacija v Sloveniji potegovala za pridobitev evropske nagrade za poslovno odličnost. Sodelovala je tudi pri nacionalnem projektu Ponudimo odraslim kakovostno izobraževanje in si kot organizacija, ki načrtno vlaga $\mathrm{v}$ kakovost, pridobila zeleni znak POKI, ki ga podeljuje Andragoški center Slovenije. Leta 2006 so v Dobi s sodelovanjem pri nacionalnem pilotnem projektu vzpostavili mesto svetovalca za kakovost izobraževanja odraslih.

\section{ZAVOD ZA IZOBRAŽEVANJE IN KULTURO ČRNOMELJ}

Včasih mislimo, da je izobraževanje odraslih mogoče razvijati le v velikih urbanih okoljih, a dejavnosti Zavoda za izobraževanje in kul- turo Črnomelj dokazujejo, da vztrajnost in sposobnost za sodelovanje odpirata vrata izobraževanja in učenja $\mathrm{v}$ vseh okoljih. Zaposleni v tem zavodu so $\mathrm{v}$ Belo krajino med prvimi $v$ Sloveniji pripeljali različne nove oblike formalnega in neformalnega izobraževanja odraslih. Sami pravijo, da je spremljanje in izboljševanje kakovosti v organizaciji povezovalni element vizije zavoda, saj le kakovostno izobraževanje zagotavlja uporabnost znanja in zadovoljstvo udeležencev. Veliko pozornost namenjajo vlaganju $\mathrm{v}$ znanje strokovnih sodelavcev in učiteljev ter zagotavljanju možnosti za njihovo delo. Menijo tudi, da je skrb za kakovost postala še načrtnejša, ko so leta 2003 začeli sodelovati pri projektu Ponudimo odraslim kakovostno izobraževanje. Od takrat deluje tudi skupina za kakovost, ki načrtuje in skrbi za uresničevanje akcijskih načrtov razvoja kakovosti. Od leta 2004 so nosilci zelenega znaka POKI, ki ga podeljuje Andragoški center Slovenije, leta 2006 pa so vzpostavili mesto svetovalke za kakovost izobraževanja odraslih. Zavod za izobraževanje in kulturo Črnomelj najbolj opredeljujeta zavezanost zaposlenih skupnim vrednotam izobraževalne organizacije in močna povezanost z lokalnim okoljem. Pripadnost, strokovnost, odprtost do okolja, povezovanje in strpnost do drugačnosti zanje niso zgolj vrednote, zapisane na papirju, temveč nekaj, kar ves čas uresničujejo pri delu.

\section{JASNA KRŽIN STEPIŠNIK}

Spremembe v izobraževalnih organizacijah so odvisne od ravnanja vodstva in učiteljev, njihovega stališča, da se je za spreminjanje vredno učiti in si vzeti čas. Za Jasno Kržin Stepišnik prav gotovo lahko rečemo, da je tak človek. Opazne strokovne ambicije je osredotočila na razvoj kakovosti izobraževanja odraslih, ob tem pa ob sebi zbrala sodelavce in navdušence ter $\mathrm{z}$ njimi 
različne zamisli uresničevala $\mathrm{v}$ praksi. Je ravnateljica Središča za izobraževanje odraslih na Biotehniškem izobraževalnem centru v Ljubljani. Svojo prvo izkušnjo pri načrtnem razvijanju kakovosti v izobraževanju odraslih je pridobila ob vključitvi v projekt Andragoškega centra Slovenije Ponudimo odraslim kakovostno izobraževanje odraslih. Ob sebi je zbrala skupino zavzetih učiteljic, z njimi v praksi preizkušala takrat šele zgolj teoretično zamišljene rešitve o izpeljevanju samoevalvacije. $\mathrm{K}$ njenemu uspešnemu delovanju za razvoj kakovosti je pripomoglo tudi to, da je za idejo kakovosti znala navdušiti vodstvo. Jasna Kržin Stepišnik je svoje delo na področju kakovosti razširila tudi zunaj šole. Tako je v letih 2004-2006 sodelovala pri projektu Konzorcija biotehniških šol Biotehniška področja, najbolj učeča se okolja prav na področju kakovosti. Še posebno dragoceno pa je, da je znanje in izkušnje, pridobljene pri presojanju in razvijanju kakovosti, pripravljena prenašati $\mathrm{v}$ presojo in učenje drugim. Tako je s strokovnimi prispevki sodelovala na nekaterih slovenskih in mednarodnih srečanjih, piše pa tudi v strokovne revije.

\section{IDA SREBOTNIK}

Ida Srebotnik v zadnjih letih dela na Šolskem centru za pošto, ekonomijo in telekomunikacije v Ljubljani, kjer je začela kot vodja izobraževanja odraslih, ki je vedno iskala nove možnosti za učenje odraslih na srednji šoli. Bila je tudi pobudnica in koordinatorica priprav novih izobraževalnih programov, tudi v višjem strokovnem izobraževanju, kjer deluje danes. Razvojna usmerjenost in predanost izobraževanju odraslih sta jo pripeljali do načrtnega dela na področju kakovosti. Bila je pobudnica za ustanovitev skupine za kakovost na šoli, od leta 2004 je predsednica komisije za spremljanje in zagotavljanje kakovosti študija na višji strokovni šoli, od leta 2006 pa tudi svetovalka za kakovost izobraževanja odraslih. Poudarimo naj njeno načrtno delo pri presojanju kakovosti izobraževanja učiteljev in strokovnih delavcev, dragocen prispevek so zagotovo njena dolgoletna prizadevanja za povezovanje učiteljev in strokovnjakov iz podjetij. O Idi Srebotnik ni mogoče govoriti, ne da bi omenili njena prizadevanja za večjo kakovost izobraževanja odraslih na nacionalni ravni. Kot članica Strokovnega sveta za izobraževanje odraslih opazno prispeva $\mathrm{k}$ stališčem Sveta in s tem k razvoju sistema izobraževanja odraslih. $\mathrm{Za}$ kakovost izobraževanja odraslih, predvsem pa za povezovanje strokovnjakov s področja izobraževanja odraslih skrbi tudi kot pobudnica ustanovitve in gibalo Društva organizacij za izobraževanje odraslih na srednjih šolah.

\section{NADA ŽAGAR}

Nada Žagar je direktorica Zavoda za izobraževanje in kulturo Črnomelj ter ena tistih vodilnih $\mathrm{v}$ omrežju izobraževanja odraslih v Sloveniji, ki je dala pomemben pečat tako razvoju lastne izobraževalne organizacije kot okolju, v katerem deluje. Čeprav se ne izogiba lastni odgovornosti, ko gre za postavljanje in uresničevanje pomembnih strateških ciljev, je ena izmed njenih odlik prav spodbujanje partnerskega sodelovanja z različnimi organizacijami pri reševanju razvojnih vprašanj lokalnega okolja. Vodi jo trdno prepričanje, da skupni projekti ljudi povezujejo ne glede na občinske meje ali kakšne druge pregrade. V svoji organizaciji ves čas skrbi, da sta kakovost in stalno izboljševanje vrednoti, ki usmerjata delo vseh zaposlenih. Pomembna je njena strokovna podpora skupini za kakovost, ki deluje v kolektivu od leta 2004, še dragocenejše pa je njeno sodelovanje pri načrtovanju in uresničevanju razvoja kakovosti. Na okolje 
vpliva zlasti s svojim zgledom, predvsem ko gre za pripadnost nenehnemu učenju, prenosu znanja na druge in ustvarjanju okoliščin, $v$ katerih sta učenje in poučevanje sproščena ter zanimiva. Posebno pozornost namenja spodbujanju izobraževanja učiteljev in strokovnih sodelavcev ter presojanju njegove kakovosti. Spodbuja razprave o različnih vidikih kakovosti na andragoških zborih in srečanjih strokovnih aktivov. Svoje izkušnje in strokovno znanje ves čas spopolnjuje z nadaljnjim študijem; tako je prav kakovosti namenila posebno pozornost $\mathrm{v}$ svojem magistrskem delu.

Vsem dobitnikom priznanj iskreno čestitamo!

Sonja Klemenčič, mag. Tanja Možina in Milena Zorić 